\title{
Genetic and biochemical differentiation in Vitis vinifera (Kabarcik) populations grown at different altitudes in Coruh Valley
}

\author{
G. Agar $^{1}$, N. Yildirim ${ }^{1}$ and S. Ercisli ${ }^{2}$ \\ ${ }^{1}$ Department of Biology, Faculty of Agriculture, Ataturk University, \\ Erzurum, Turkey \\ ${ }^{2}$ Department of Horticulture, Faculty of Agriculture, \\ Ataturk University, Erzurum, Turkey \\ Corresponding author: N. Yildirim \\ E-mail: nalanyild@hotmail.com
}

Genet. Mol. Res. 11 (1): 211-220 (2012)

Received March 14, 2011

Accepted November 3, 2011

Published February 3, 2012

DOI http://dx.doi.org/10.4238/2012.February.3.1

\begin{abstract}
We examined genetic differences of four Vitis vinifera populations (A, B, C, D) including local Kabarcik cultivar grown along an altitude gradient of $800,900,1000$, and $1150 \mathrm{~m}$ above sea level in the Coruh Valley ( $800 \mathrm{~m}$ : A population; $900 \mathrm{~m}$ : B population; 1000 $\mathrm{m}$ : C population; $1150 \mathrm{~m}$ : D population). Leaf samples were used for both RAPD and fatty acid analysis. A total of 60 individuals with 15 individuals per population were included in this study. RAPD analyses showed various band sizes, which ranged from 250 to $3000 \mathrm{bp}$. Mean polymorphic locus ratios were determined as $96.29 \%$ considering four populations. The highest percentage of polymorphic loci (97.8\%) was produced by the highest altitude. Thirty-two different fatty acids were found; linoleic acid was the most common in all four populations. According to the dendograms obtained from statistical analyses of RAPD and fatty acid profiles the populations that were close to each other in terms of geographical distance also were similar genetically.
\end{abstract}

Key words: FAME; RAPD; Vitis vinifera; Genetic distance; Altitude 


\section{INTRODUCTION}

Grape (Vitis vinifera) belongs to the Vitaceae family and is one of the oldest cultivated fruits in the world. Grapevines have been cultivated for about 5000 years (Zohary and Hope, 2000). The Eurasian grape (Vitis vinifera L.) is the most widely cultivated and economically important fruit crop in the world (Vivier and Pretorius, 2002). In V. vinifera L. around 6000 cultivars are estimated to exist (Alleweldt and Dettweiler, 1994), of which less than 400 are of commercial importance (Galet, 2000). It is of great economic importance, and its fruit is mostly used for transformation into valuable beverages such as wines and spirits. Each Anatolia region claims its own cultivars and wines.

During cultivation, populations of cultivated plants are subject to strong selective pressures, e.g., human determination of morphological, physiological and behavioral changes in the organisms (Otero-Arnaiz et al., 2005). This process has greatly modified the natural mating systems and dispersal mechanisms of plant species (Pickersgill, 1969), as well as their morphology, physiology and genetic structures (Doebley, 1989; Buckler et al., 2001; Hernández-Verdugo et al., 2001; Zeder et al., 2006). The genetic structures of cultivated plant populations have been shaped by many factors over the course of cultivation (Hernández-Verdugo et al., 2001; Oyama et al., 2006).

Many molecular genetic markers have been used in detecting population genetic structure since 1966. Among them, random amplified polymorphic DNA (RAPD) is easy to use. RAPD has become an increasingly popular tool in genetic studies of natural plant populations (Nybom and Bartish, 2000). RAPD markers developed during the last two decades have been successfully and widely utilized for taxonomic and systematic classification as well as phylogenic and genetic diversity studies of plants (Rath et al., 1998; Sun et al., 2005; Meimberg et al., 2006; Hug and Roger, 2007). The RAPD technique has several advantages over isozyme and other DNA markers, including speed, low cost, and the use of small amounts of plant material. It has therefore been widely used for estimating genetic diversity and relatedness in plant populations (Huff et al., 1993; Heum et al., 1994; Ge et al., 1999).

Genetic diversity of plant species can significantly change with the variation of altitudes that regulate ecological conditions in a particular plant habitat (Gail et al., 1998; Hsiao and Lee, 1999; George et al., 2001; Erich and Johann, 2003; Semang et al., 2003; Feng et al., 2004). Consequently, a change of genetic diversity in plant populations along an altitude gradient becomes an increasingly attractive subject both for theoretical interests and conservation practices because sometimes a relatively small change in altitude can cause a drastic change in environmental conditions, such as temperature and moisture (Heath and Williams, 1979; Baur and Raboud, 1988). Previous studies have shown that the genetic diversity of plant populations may increase (Yan et al., 1999), decrease (Gail et al., 1998; Zhao et al., 2001) or fluctuate to a large extent (Li et al., 1998), with an increase in altitude.

In the present study, we investigated the level and pattern of genetic variation at RAPD markers in four populations of $V$. vinifera (Kabarcik) along an altitude gradient ranging from 800 to $1150 \mathrm{~m}$ above sea level in the Erzurum.

\section{MATERIAL AND METHODS}

\section{Plant material}

Four cultivated (A, B, C, D) populations of $V$. vinifera (Kabarcik) were sampled along 
an altitude gradient - 800, 900, 1000, and $1150 \mathrm{~m}$ above sea level - in the Coruh Valley (800 m: A population; $900 \mathrm{~m}$ : B population; $1000 \mathrm{~m}$ : C population; $1150 \mathrm{~m}$ : D population). A total of 60 individuals with 15 individuals per population were included in this study.

\section{Extraction and analysis of FAME}

Preparation and analysis of FAME from whole cell fatty acids from plant samples were performed according to the method described in the manufacturer manual (Sherlock Microbial Identification System version 4.5, MIDI Inc., Newark, DE, USA). Plant leaves were powdered after lyophilization in liquid nitrogen. Approximately $40 \mathrm{mg}$ powdered leaf material from each sample was added to $1 \mathrm{~mL} 1.2 \mathrm{M} \mathrm{NaOH}$ in $50 \%$ aqueous methanol with 5 glass beads ( $3 \mathrm{~mm}$ in diameter) in a screw cap tube, then incubated at $100^{\circ} \mathrm{C}$ for $30 \mathrm{~min}$ in a water bath. After the saponified samples were cooled at room temperature for $25 \mathrm{~min}$, they were acidified and methylated by adding $2 \mathrm{~mL} 54 \% 6 \mathrm{~N} \mathrm{HCl}$ in $46 \%$ aqueous methanol and incubated at $80^{\circ} \mathrm{C}$ for $10 \mathrm{~min}$ in a water bath. After rapid cooling, methylated fatty acids were

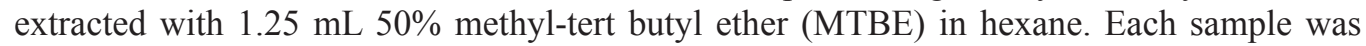
mixed for $10 \mathrm{~min}$ and the bottom phase was removed with a Pasteur pipette. The top phase was washed with $3 \mathrm{~mL} 0.3 \mathrm{M} \mathrm{NaOH}$. After mixing for $5 \mathrm{~min}$, the top phase was then removed for analysis. Following the base wash step, the extract (FAME) was cleaned in anhydrous sodium sulfate and then transferred to a GC sample vial for analysis.

FAME were separated by gas chromatography (HP6890, Hewlett Packard, Palo Alto, CA, USA) with a fused-silica capillary column $(25 \mathrm{~m}$ by $0.2 \mathrm{~mm})$ with cross-linked $5 \%$ phenyl methyl silicone. The operating parameters for the study were set and controlled automatically by a computer program. The chromatograms with peak retention times and areas were produced on the recording integrator and were electronically transferred to the computer for analysis, storage and report generation. Peak naming and column performance were achieved through the use of Eukary calibration standard mix (Microbial ID 1201-A) containing nC9nC30 saturated and 2- and 3-hydroxy fatty acids. Cellular fatty acids were identified on the basis of equivalent chain length data. FAME profiles of each plant species tested were identified by comparing the commercial databases (Eukary) with the MIS software package.

\section{DNA extraction and polymerase chain reaction (PCR) amplification}

Genomic DNA was extracted from powdered plant materials using frozen nitrogen, as described by Lin et al. (2001).

\section{RAPD}

Samples were screened for RAPD variation using standard 10 base primers supplied by Operon. Thirty microliters of reaction cocktail was prepared as follows: $3.0 \mu \mathrm{L} 10 \mathrm{X}$ buffer, $1.2 \mu \mathrm{L} 10 \mathrm{mM}$ dNTPs, $1.2 \mu \mathrm{L} 25 \mathrm{mM}$ magnesium chloride, $2.0 \mu \mathrm{L} 5 \mu \mathrm{M}$ primer, $0.4 \mu \mathrm{L} 5$ U Taq polymerase, $19.2 \mu \mathrm{L}$ water, and $3.0 \mu \mathrm{L}$ DNA sample $(100 \mathrm{ng} / \mu \mathrm{L})$. A total of $35 \mathrm{RAPD}$ primers were tested and among them 10 primers producing reproducible banding patterns were selected. Therefore, the results are based on 10 primers. The thermal cycler (Eppendorf Company) was programmed for $2 \mathrm{~min}$ at $95^{\circ} \mathrm{C} ; 2$ cycles of $30 \mathrm{~s}$ at $95^{\circ} \mathrm{C}, 1 \mathrm{~min}$ at $37^{\circ} \mathrm{C}, 2 \mathrm{~min}$ at 
$72^{\circ} \mathrm{C} ; 2$ cycles of $30 \mathrm{~s}$ at $95^{\circ} \mathrm{C}, 1 \mathrm{~min}$ at $35^{\circ} \mathrm{C}, 2 \mathrm{~min}$ at $72^{\circ} \mathrm{C} ; 41$ cycles of $30 \mathrm{~s}$ at $94^{\circ} \mathrm{C}, 1 \mathrm{~min}$ at $35^{\circ} \mathrm{C}, 2$ min at $72^{\circ} \mathrm{C}$; followed by a final 5 -min extension at $72^{\circ} \mathrm{C}$, then brought down to $4^{\circ} \mathrm{C}$.

\section{Electrophoresis}

The PCR products $(27 \mu \mathrm{L})$ were mixed with $6 \mathrm{X}$ gel loading buffer $(3 \mu \mathrm{L})$ and loaded onto an agarose $(1.5 \%$, w/v) gel electrophoresis in $0.5 \mathrm{X}$ TBE (Tris-borate-EDTA) buffer at $70 \mathrm{~V}$ for $150 \mathrm{~min}$. The gel was stained in ethidium bromide solution ( $2 \mu \mathrm{LEtbr} / 100 \mathrm{~mL} 1 \mathrm{X}$ TBE buffer) for $40 \mathrm{~min}$ and visualized under UV in Bio Doc Image Analysis System with Uvisoft analysis package (Cambridge, UK).

\section{Data analysis}

Amplified DNA fragments were scored by the presence (1) or absence (0) for each DNA sample, which formed a matrix of the RAPD phenotypes. For FAME analysis, fatty acids of each plant species were scored as present $(0.1-100 \%)$ or absent $(0 \%)$. The genetic distance or similarity was determined by Jaccard (1908) similarity index. The pairwise genetic distances of the samples were used to construct a dendogram using the unweighted pair group method of arithmetic average (UPGMA).

\section{RESULTS AND DISCUSSION}

Results of the RAPD analysis are summarized in Table 1. In total, 132 bands were generated from 60 individuals from the 4 populations using 10 primers. The highest number of bands (23) was produced by OPB-8 and the lowest number bands (7) was produced by OPW4. The size of the amplified fragments ranged from 250 to $3000 \mathrm{bp}$. The percentage of polymorphic loci across populations varied between 94.6 and $97.8 \%$, with an average of $96.29 \%$. The highest percentage of polymorphic loci, $97.8 \%$, was produced by the $\mathrm{D}$ population.

\begin{tabular}{|c|c|c|c|c|c|c|c|}
\hline Primer code & Sequence $5^{\prime} \rightarrow 3^{\prime}$ & Total bands & A population & B population & C population & D population & $\begin{array}{l}\text { Range of fragment } \\
\text { size (bp) }\end{array}$ \\
\hline OPA-4 & AATCGGGCTG & 16 & 12 & 16 & 10 & 15 & $250-3000$ \\
\hline OPB- 8 & GTCCACACGG & 23 & 23 & 11 & 7 & 12 & $300-2500$ \\
\hline OPB-10 & CTGCTGGGAC & 12 & 8 & 10 & 12 & 12 & $500-2700$ \\
\hline OPH-17 & САСТСТССТС & 15 & 13 & 4 & 10 & 15 & $500-2900$ \\
\hline OPW-4 & CAGAAGCGGA & 7 & 7 & 5 & 7 & 6 & $400-1900$ \\
\hline OPW-7 & CTGGACGTCA & 11 & 11 & 9 & 4 & 4 & $500-1700$ \\
\hline OPW-11 & CTGATGCGTG & 12 & 3 & 12 & 5 & 2 & $700-2000$ \\
\hline OPW-13 & CACAGCGACA & 15 & 7 & 12 & 15 & 4 & $400-2500$ \\
\hline OPW-17 & GTCCTGGGTT & 12 & 5 & 11 & 3 & 12 & $600-3000$ \\
\hline OPW-20 & TGTGGCAGCA & 9 & 3 & 7 & 2 & 9 & $500-1900$ \\
\hline $\begin{array}{l}\text { Total \% } \\
\text { polymorphism }\end{array}$ & & 132 & 95.83 & 96.90 & 94.66 & 97.80 & \\
\hline
\end{tabular}

The 10 random primers generated a total of 92 RAPD bands in the A population. The size of the amplified fragments ranged from 600 to $2500 \mathrm{bp}$. OPB- 8 gave the highest number of RAPD products, while OPW-11 and OPW-20 gave equally the lowest numbers. In total, $95.83 \%$ of the bands were polymorphic. 
The 10 random primers generated a total of 97 RAPD bands in the B population. The size of the amplified fragments ranged from 250 to $3000 \mathrm{bp}$. Primers OPA-4 and OPH-17 gave the highest and lowest number of RAPD products, respectively. In total, $96.90 \%$ of the bands were polymorphic.

The 10 random primers generated a total of 75 RAPD bands in the $C$ population. The size of the amplified fragments ranged from 400 to $2100 \mathrm{bp}$. Primers OPW-13 and OPW-20 gave the highest and lowest number of RAPD products, respectively. In total, $94.66 \%$ of the bands were polymorphic.

The 10 random primers generated a total of 91 RAPD bands in the D population. The size of the amplified fragments ranged from 250 to 3000 bp. Primers OPA-4, OPH-17 and OPW-11 gave the highest to lowest number of RAPD products, respectively, in descending order. In total, $97.8 \%$ of the bands were polymorphic. Banding patterns of the D population genotypes using the primer OPB-8 are illustrated in Figure 1. The dendrogram created from the RAPD markers grouped the 4 populations into three major clusters (Figure 2). Cluster 1 formed the A population, Cluster 2 formed the B population. Cluster 3 was divided into 2 subclusters and $\mathrm{C}$ and $\mathrm{D}$ populations formed a subcluster. The genetic distance between the population $\mathrm{A}$ and $\mathrm{D}(0.335)$ is high. The dendrogram clearly shows that each population is genetically differentiated from the other populations.

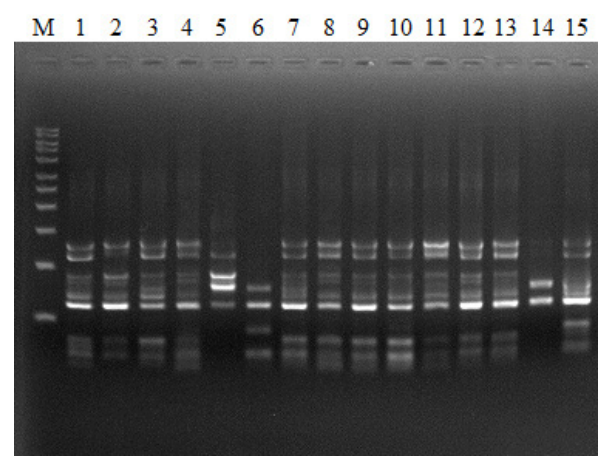

Figure 1. Amplification products generated from 15 individuals of D populations of Vitis vinifera (Kabarc1k) using primer OPB-8. $\mathrm{M}=$ molecular marker.

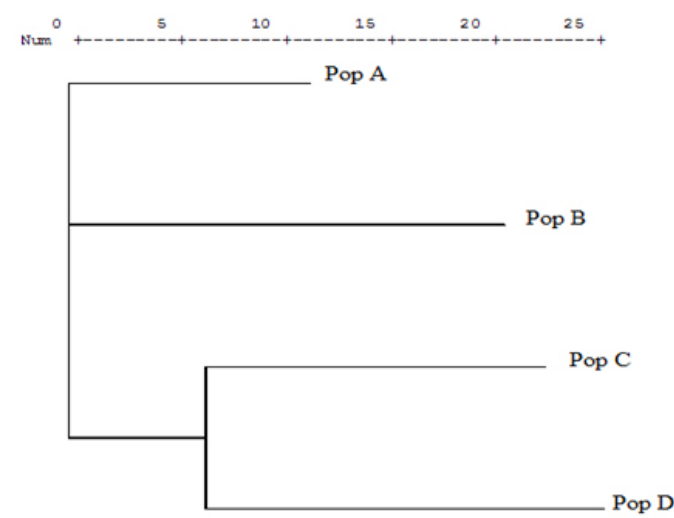

Figure 2. Dendrogram of genetic distances based on RAPD 4 populations of Vitis vinifera (Kabarc1k). 
RAPD analyses showed various band sizes, which ranged between 250 and $3000 \mathrm{bp}$. Mean polymorphic locus ratios were determined to be $96.29 \%$. The highest percentage of polymorphic loci, $97.8 \%$, was produced by the D population. High polymorphism explains the rich genetic resource of $V$. vinifera (Kabarcik).

The percent of fatty acid content of $V$. vinifera (Kabarcik) for the A population is presented in Table 2. As seen in the Table, the A population has 13 kinds of fatty acids and their fatty acid content ranged from $1.23 \%(14: 0)$ to $78.78 \%(18: 1: \omega 9 \mathrm{c})$. All individuals had 16:0 and 18:1: $\omega 9 \mathrm{c}$ content that ranged between $11.21-26.96$ and $33.37-78.78 \%$, respectively. $14: 0$, 10:0 $3 \mathrm{OH}, 12: 1: \omega 8 \mathrm{c}, 16: 1: \omega 3 \mathrm{c}, 24: 5: \omega 3$, and Cis 9,10 epoxy 18:0 are rarely seen and found in low concentrations. Oleic $(18: 1 ; 33.37$ to $78.78 \%$ within population) acid forms the bulk of the total fatty acids found. Biochemical similarity index amongst the individuals of the A population ranged between 0.222 and 1.000 .

\begin{tabular}{|c|c|c|c|c|c|c|c|c|c|c|c|c|c|c|c|}
\hline Fatty acids & 1 & 2 & 3 & 4 & 5 & 6 & 7 & 8 & 9 & 10 & 11 & 12 & 13 & 14 & 15 \\
\hline $14: 0$ & - & - & - & - & - & - & - & - & - & - & - & - & 1.23 & - & - \\
\hline $10: 03 \mathrm{OH}$ & - & - & - & - & - & 1.77 & - & - & - & - & - & - & - & - & - \\
\hline $12: 1: \omega 8 \mathrm{c}$ & - & - & - & - & - & 1.54 & - & - & - & - & - & - & - & - & - \\
\hline $16: 0$ & 26.96 & 11.39 & 15.27 & 20.69 & 19.43 & 14.18 & 14.32 & 14.68 & 21.22 & 11.28 & 17.07 & 12.71 & 11.21 & 15.09 & 19.62 \\
\hline $16: 1: \omega 3 c$ & - & - & - & - & - & - & 3.06 & - & - & - & - & - & - & - & - \\
\hline $18: 1 \omega 9 \mathrm{c}$ & 33.37 & 64.53 & 63.65 & 64.93 & 41.67 & 60.11 & 69.01 & 64.45 & 78.78 & 46.20 & 65.12 & 46.64 & 58.04 & 75.04 & 68.12 \\
\hline $21: 1: \omega 7 \mathrm{c}$ & 39.67 & - & - & - & 20.43 & - & - & - & - & - & - & 14.19 & - & - & - \\
\hline $24: 5: \omega 3$ & - & - & - & - & - & 2.67 & - & - & - & - & - & - & - & - & - \\
\hline $25: 03 \mathrm{OH}$ & - & - & - & - & 18.47 & - & - & - & - & - & - & - & - & - & - \\
\hline $26: 03 \mathrm{OH}$ & - & 18.71 & 11.50 & 14.38 & - & 13.90 & 13.61 & 16.12 & - & - & 16.58 & 26.46 & 30.75 & 8.09 & 12.26 \\
\hline $28: 0$ & - & - & 9.57 & - & - & 5.84 & - & - & - & - & - & - & - & - & - \\
\hline $\mathrm{C} 25 \mathrm{~N}$ alcohol & - & 5.37 & - & - & - & - & - & 4.75 & - & 36.22 & - & - & - & - & - \\
\hline Cis 9,10 epoxy $18: 0$ & - & - & - & - & - & - & - & - & - & 6.30 & - & - & - & - & - \\
\hline
\end{tabular}

The B population contains the highest fatty acids of all the populations. Table 3 represents the percent fatty acid content of the B population. The population contains 22 different fatty acids in a range of $1.03 \%$ (C21 primary alcohol) to $72.93 \%(18: 1: \omega 9 \mathrm{c})$. All individuals

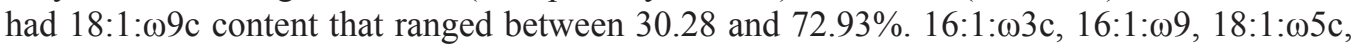
18:0, 19:1: $\omega 7 \mathrm{c}, 20: 0,24: 5: \omega 3,28: 0$, ISO 17:1 G are rarely seen and found in low concentrations. ISO 17:1 AT9 and ISO 17:G are found only in three individuals in a range of 2.20$5.29 \%$. Oleic $(18: 1 ; 2.17$ to $72.38 \%$ within population) acid forms the bulk of the total fatty acids found. Biochemical similarity index amongst the individuals in the B population ranged between 0.111 and 1.000 .

Table 4 represents the percent fatty acid content of the $\mathrm{C}$ population. The population contains 13 different fatty acids in a range of $0.96 \%(24: 02 \mathrm{OH})$ to $76.74 \%(18: 1: \omega 9 \mathrm{c})$. All individuals had 16:0 and 18:1: w9c content that ranged between 11.93 and 29.19\%, 45.81 and

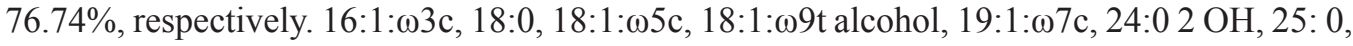
and 28: 0 are rarely seen and found in low concentrations. Oleic $(18: 1 ; 1.28$ to $76.74 \%$ within the population) acid forms the bulk of the total fatty acids found. 24:0 $2 \mathrm{OH}$ was found only in the $\mathrm{C}$ population. Biochemical similarity index amongst the individuals of the $\mathrm{C}$ population ranged between 0.222 and 1.000 .

Table 5 represents the percent fatty acid content of the D population. The population contains 21 different fatty acids in a range of $1.76 \%(16: 1: \omega 9)$ to $69.79 \%(18: 1: \omega 9 \mathrm{c})$.

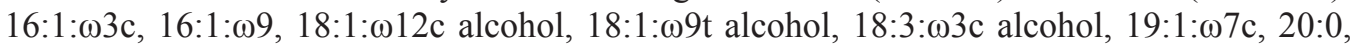


Table 3. Composition of fatty acids of the B population.

\begin{tabular}{|c|c|c|c|c|c|c|c|c|c|c|c|c|c|c|c|}
\hline Fatty acids & 1 & 2 & 3 & 4 & 5 & 6 & 7 & 8 & 9 & 10 & 11 & 12 & 13 & 14 & 15 \\
\hline 16:0 & 17.09 & 13.59 & 20.49 & 10.84 & 13.39 & 14.51 & - & 19.34 & 16.94 & 11.70 & 11.10 & 14.18 & 15.06 & 15.06 & 7.91 \\
\hline $16: 1: \omega 3 \mathrm{c}$ & - & 2.29 & - & - & 2.28 & - & - & - & - & - & - & 2.54 & - & - & - \\
\hline $16: 1$ cis $7 \mathrm{DMA}(\omega 9)$ & - & - & - & - & 2.41 & - & - & - & - & - & - & - & - & - & - \\
\hline $8: 1: \omega 5 c$ & - & - & - & - & - & 2.20 & - & - & - & - & - & - & - & - & - \\
\hline $18: 1: \omega 6 \mathrm{c}$ & - & - & 13.72 & 12.48 & - & - & 22.41 & - & - & - & - & - & 13.29 & - & - \\
\hline $18: 1: \omega 9 c$ & 72.38 & 64.14 & 41.77 & 60.28 & 63.86 & 69.74 & 31.56 & 67.74 & 42.99 & 62.28 & 44.64 & 70.61 & 30.28 & 72.93 & 49.45 \\
\hline 18:1: $\omega 9 \mathrm{t}$ alcohol & 2.78 & - & - & 2.17 & 2.62 & - & - & - & 2.68 & - & - & - & 4.24 & - & - \\
\hline 18:1: $\omega 12 \mathrm{c}$ alcohol & - & - & 6.88 & - & - & - & 10.03 & - & - & - & - & - & 4.29 & - & - \\
\hline 18:0 & - & - & - & - & - & 1.34 & - & 1.81 & 1.92 & - & - & - & - & - & - \\
\hline $19: 1: \omega 7 \mathrm{c}$ & - & 3.79 & - & - & 2.81 & - & - & - & - & - & - & - & - & - & - \\
\hline $20: 0$ & - & - & - & - & - & - & - & - & 1.82 & - & - & - & - & - & - \\
\hline $1: 1: a$ & - & - & 11.86 & - & - & - & 26.77 & - & - & - & - & - & - & - & - \\
\hline $2: 03$ & - & - & - & - & - & - & - & - & - & - & - & - & 6.91 & - & - \\
\hline $4: 5: \omega 3$ & - & - & - & - & - & - & - & - & 2.20 & - & - & - & - & - & - \\
\hline $25: 0$ & - & - & - & - & - & - & 9.23 & - & - & - & - & - & 6.33 & - & - \\
\hline $26: 03 \mathrm{OH}$ & 7.75 & 16.18 & - & 14.23 & 10.42 & - & - & - & 5.38 & - & 25.21 & - & - & 12.02 & - \\
\hline 28:0 & - & - & - & - & - & - & - & - & - & - & 3.29 & - & - & - & - \\
\hline ISO 17:1 AT9 & - & - & 5.29 & - & - & - & - & - & - & - & - & - & 3.95 & - & - \\
\hline ISO $17: 1 \mathrm{G}$ & - & - & - & - & 2.20 & - & - & - & - & - & - & - & - & - & - \\
\hline C21 primary & - & - & - & - & - & 12.41 & 1.41 & - & 1.03 & - & - & 1.47 & - & 1.76 & - \\
\hline $\mathrm{C} 25$ & - & - & - & - & - & - & - & - & - & 21.67 & 15.76 & 12.67 & - & - & 36.55 \\
\hline Cis 9,10 epoxy $18: 0$ & - & - & - & - & - & - & - & - & - & 4.36 & - & - & - & - & 6.10 \\
\hline
\end{tabular}

\begin{tabular}{|c|c|c|c|c|c|c|c|c|c|c|c|c|c|c|c|}
\hline Fatty acids & 1 & 2 & 3 & 4 & 5 & 6 & 7 & 8 & 9 & 10 & 11 & 12 & 13 & 14 & 15 \\
\hline $16: 0$ & 23.26 & 13.25 & 29.19 & 12.11 & 19.49 & 22.57 & 17.93 & 21.34 & 20.94 & 13.27 & 26.56 & 20.67 & 11.93 & 21.85 & 21.87 \\
\hline $16: 1: \omega 3 c$ & - & - & - & - & - & - & - & 2.57 & - & - & 2.45 & 2.13 & - & - & - \\
\hline $18: 0$ & - & - & - & - & - & 2.39 & 1.28 & - & 1.83 & - & - & - & - & 1.62 & 1.73 \\
\hline $18: 1: \omega 5 c$ & - & - & - & - & - & - & - & - & - & - & - & - & 6.54 & - & - \\
\hline $18: 1: \omega 9 c$ & 76.74 & 52.46 & 70.81 & 58.21 & 62.79 & 59.06 & 45.81 & 55.32 & 58.51 & 46.59 & 62.31 & 63.39 & 71.31 & 58.75 & 56.88 \\
\hline 18:1:œ9t alcohol & - & - & - & - & - & - & - & - & - & - & - & - & - & - & 1.40 \\
\hline $21: 1: \omega 7 \mathrm{c}$ & - & 13.39 & - & - & - & - & - & - & - & - & - & - & - & - & - \\
\hline $19: 1: \omega 7 \mathrm{c}$ & - & - & - & - & - & - & 2.25 & - & - & 4.51 & - & - & - & - & - \\
\hline $24: 02 \mathrm{OH}$ & - & - & - & - & - & - & 0.96 & - & - & - & - & - & - & - & - \\
\hline $25: 0$ & - & 4.13 & - & - & - & - & - & - & - & - & - & - & - & - & - \\
\hline $26: 03 \mathrm{OH}$ & - & 16.77 & - & 29.68 & 17.72 & - & - & 19.69 & 6.64 & 35.64 & 8.69 & 13.80 & 10.22 & - & - \\
\hline $28: 0$ & - & - & - & - & - & 0.98 & - & 1.09 & - & - & - & - & - & - & - \\
\hline C21 primary alcohol & - & - & - & - & - & 15.00 & 31.77 & - & 12.88 & - & - & - & - & 17.78 & 13.51 \\
\hline
\end{tabular}

Table 5. Composition of fatty acids of the D population.

\begin{tabular}{|c|c|c|c|c|c|c|c|c|c|c|c|c|c|c|c|}
\hline Fatty acids & 1 & 2 & 3 & 4 & 5 & 6 & 7 & 8 & 9 & 10 & 11 & 12 & 13 & 14 & 15 \\
\hline$\overline{16: 0}$ & 13.25 & 16.78 & - & 12.87 & - & 23.90 & 18.11 & 16.76 & 11.91 & 13.54 & 14.37 & 15.63 & 27.68 & 24.55 & 20.18 \\
\hline $16: 1: \omega 3 \mathrm{c}$ & - & - & - & - & - & 3.51 & - & - & - & - & - & - & - & - & - \\
\hline $16: 1: 09$ & - & - & - & - & - & - & 1.76 & - & - & - & - & - & - & - & - \\
\hline $8: 1: \omega 9 c$ & 66.37 & 69.79 & 48.28 & 57.56 & 32.01 & 63.37 & 65.46 & 41.96 & 40.25 & - & 62.14 & 44.21 & 22.95 & - & 48.86 \\
\hline $8: 1: \omega 6 \mathrm{c}$ & 18.35 & - & 19.91 & - & - & - & - & - & - & 3.81 & - & 9.60 & 14.62 & - & 13.25 \\
\hline 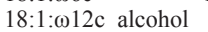 & - & - & 4.79 & - & - & - & - & - & - & - & - & - & - & - & - \\
\hline 18:1: $\omega 9 \mathrm{t}$ alcohol & - & - & - & - & - & - & 3.29 & - & - & - & - & - & - & - & - \\
\hline $11 \mathrm{c}$ & - & - & - & - & - & - & - & - & - & 58.86 & - & - & - & - & - \\
\hline ohol & - & - & 4.79 & - & - & - & - & - & - & - & - & - & - & - & - \\
\hline $18: 3: \omega 6 c$ & - & - & - & - & - & - & - & 8.81 & 7.27 & 8.71 & - & - & - & - & - \\
\hline $20: 0$ & - & - & - & - & - & - & - & 7.12 & - & - & - & - & - & - & - \\
\hline $.3: \omega 6$ & - & - & - & - & 30.20 & - & - & - & - & - & - & - & - & - & - \\
\hline 19:1: $\omega$ & - & - & - & - & - & 3.14 & 2.07 & - & 4.79 & - & - & - & - & - & - \\
\hline $21: 1: \omega 7 \mathrm{c}$ & - & - & 24.38 & - & 37.80 & - & - & - & - & 6.33 & - & 25.81 & 28.52 & 30.94 & 17.71 \\
\hline $22: 03 \mathrm{OH}$ & - & - & - & - & - & - & - & - & - & - & - & 4.75 & - & 30.19 & - \\
\hline $25: 0$ & - & - & 2.64 & - & - & - & - & - & - & - & - & - & 6.23 & - & - \\
\hline $25: 0$ & 3.03 & - & - & - & - & - & - & - & - & - & - & - & - & 14.32 & - \\
\hline $26: 03 \mathrm{OH}$ & - & 13.43 & - & 29.57 & - & 6.07 & 9.30 & - & 30.40 & 8.74 & - & - & - & - & - \\
\hline 28.0 & - & - & - & - & - & - & - & 2.2 & - & - & 4.00 & - & - & - & - \\
\hline $\mathrm{C} 20 \mathrm{~N}$ & - & - & - & - & - & - & - & 8.3 & 5.38 & - & - & - & - & - & - \\
\hline C21 primary alcohol & $1-$ & - & - & - & - & - & - & 14.73 & - & - & 19.49 & - & - & - & - \\
\hline
\end{tabular}


25:0, and 28:0 are rarely seen and found in low concentrations. 18:1:œ11c had only one individual and a range of $58.86 \%$. Differing from the other population, some individuals were

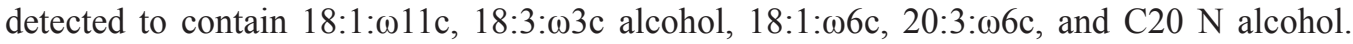
Oleic (18:1: $\omega 9 \mathrm{c} ; 22.95$ to $69.79 \%$ within the population) acid forms the bulk of the total fatty acids found. Biochemical similarity index amongst the individuals of the $\mathrm{D}$ population ranged between 0.100 and 0.989 . The dendrogram realized from the FAME grouped the 4 populations into two major clusters (Figure 3). Cluster 1 formed populations A and B. Cluster 2 formed populations $\mathrm{C}$ and $\mathrm{D}$.

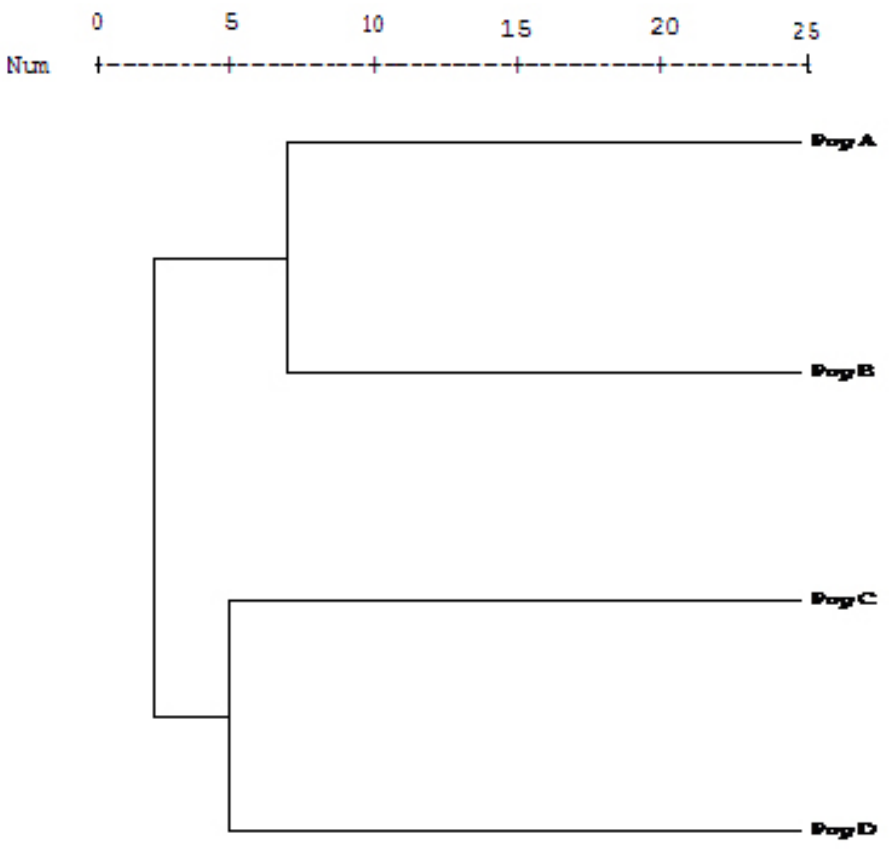

Figure 3. Dendrogram of genetic distances based on FAME 4 populations of Vitis vinifera (Kabarc1k).

According to the fatty acid profile, 32 different fatty acids were determined and oleic acid had the highest ratio in all the populations studied. The B population contains the highest fatty acids of all the populations. Ecological factors cause the differences observed in fatty acids of plant populations. These factors include temperature, location, soil structure, altitude, rain, average sun radiation, and nutrition (Hou et al., 2006).

According to the dendograms obtained from statiscal analyses of RAPD and fatty acid profiles, the populations, which are close to each other geographically, are also genetically similar. Genetic diversity showed a relationship with the geographical origin. There was an association between biochemical diversity and molecular diversity.

An association between altitudes and genetic diversity of plants has been reported in different studies (Sabrina and Sabri, 1999; George et al., 2001; Erich and Johann, 2002). These studies showed different results owing to the plant materials with different characters (e.g., breeding system, bio-geographical distribution), sampling strategy (on a large or small 
geographical scale), and various molecular markers. In macro-scale regions, the reproductive isolation of plants growing at high and low altitude is often observed in favor of high altitude. At the micro-environment level, breeding systems and seed dispersal can influence genetic diversity and differentiation among different populations (Bockelmann et al., 2003).

Clonality and spatial isolation of populations may lower genetic diversity within and increase genetic separation among populations (Barrett and Kohn, 1991; McLellan et al., 1997; Gaudeul et al., 2000; Landergott et al., 2001; Cheon et al., 2002; Despres et al., 2002). Molecular variation within populations was also correlated with the altitude of the population. Changes in population genetic variability due to ecological conditions are rarely observed (Shimizu et al., 2002; Young et al., 2002). The Parnassia palustris habitat type affected neither within-population genetic diversity nor genetic and phenotypic differentiation among populations (Bonnin et al., 2002) and in the alpine Saxifraga oppositifolia no effect was detected for altitude on genetic population variability (Gugerli et al., 1999). Along environmental gradients, several parameters such as individual age, overlap of generations, or recruitment frequency in climatically favorable years may change and influence intrapopulation genetic variation.

\section{REFERENCES}

Alleweldt G and Dettweiler E (1994). The Genetic Resources of Vitis: World List of Grapevine Collections. 2nd edn. Geilweilerhof. Institute for Grape Breeding, Siebeldingen.

Barrett SCH and Kohn JR (1991). Genetic and Evolutionary Consequences of Small Population Size in Plants: Implications for Conservation. In: Genetics and Conservation of Rare Plants (Falk DA and Holsinger KE, eds.). Oxford University Press, Oxford, 3-30.

Baur B and Raboud C (1988). Life history of the snail Arianta arbustorum along an altitudinal gradient. J. Anim. Ecol. 57: 71-87.

Bockelmann AC, Reusch TBH, Bijsma R and Bakker JP (2003). Habitat differentiation vs. isolation-by-distance: the genetic population structure of Elymus athericus in European salt marshes. Mol. Ecol. 12: 505-515.

Bonnin I, Colas B, Bacles C, Holl AC, et al. (2002). Population structure of an endangered species living in contrasted habitats: Parnassia palustris (Saxifragaceae). Mol. Ecol. 11: 979-990.

Buckler ES, Thornsberry JM and Kresovich S (2001). Molecular diversity, structure and domestication of grasses. Genet. Res. 77: 213-218.

Cheon CP, Chung MY, Chung SG and Chung MG (2002). Allozyme variation of a small subshrub Ardisia japonica (Myrsinaceae) in north eastern Asia. Silvae Genet. 51: 1-6.

Despres L, Loriot S and Gaudeul M (2002). Geographic pattern of genetic variation in the European globeflower Trollius europaeus L. (Ranunculaceae) inferred from amplified fragment length polymorphism markers. Mol. Ecol. 11: 2337-2347.

Doebley J (1989). Isozymic evidence and evolution of crop plants. In: Isozymes in Plant Biology (Soltis ED and Soltis PM, eds.). Dioscorides, Portland, 165-191.

Erich G and Johann JS (2002). Phenotypic and isozyme variation in Cystopteris fragilis (Pteridophyta) along an altitudinal gradient in Switzerland. Flora 197: 203-213.

Feng FJ, Wang FY and Li CS (2004). Genetic differentiation of Pinus koraiensis under different altitude conditions in Changbai Mountains. J. Northeast Univ. 32: 1-3.

Gail R, Dennis F, Stuart DM and Rogers HJ (1998). Genome size is negatively correlated with altitude in natural populations of Dactylis glomerata. Ann. Bot. 82: 99-105.

Galet P (2000). Dictionnaire Encyclopédique des Cepages. Hachette Pratique, Paris.

Gaudeul M, Taberlet P and Till-Bottraud I (2000). Genetic diversity in an endangered alpine plant, Eryngium alpinum L. (Apiaceae), inferred from amplified fragment length polymorphism markers. Mol. Ecol. 9: 1625-1637.

Ge S, Oliveira GC, Schaal BA, Gao LZ, et al. (1999). RAPD variation within and between natural populations of the wild rice Oryza rufipogon from China and Brazil. Heredity 82 (Pt 6): 638-644.

George T, Latha J, George V, Klyanaraman SK, et al. (2001). Analysis of phenotypic and genetic variations among populations of Oryza malampuzhaensis show evidence of altitude-dependent genetic changes. Can. J. Bot. 79: 1090-1098.

Gugerli F, Eichenberger K and Schneller JJ (1999). Promiscuity in populations of the cushion plant Saxifraga oppositifolia in the Swiss Alps as inferred from random amplified polymorphic DNA (RAPD). Mol. Ecol. 8: 453-461. 
Heath D and Williams DR (1979). Life at High Altitude. Edward Arnold, London.

Hernández-Verdugo S, Luna-Reyes R and Oyama K (2001). Genetic structure and differentiation of wild and domesticated populations of Capsicum annuum from Mexico. Plant Syst. Evol. 226: 129-142.

Heum M, Murrhy JP and Phillips TD (1994). A comparison of RAPD and isozyme analyses for determining the genetic relationships among Avena sterilis L. accessions. Theor. Appl. Genet. 87: 689-696.

Hou G, Abblett GR, Pauls KP and Rajcan I (2006). Environmental effects on fatty acid levels in soybean seed oil. Jaocs 83: 759-763.

Hsiao JY and Lee SM (1999). Genetic diversity and microgeographic differentiation of Yushan cane (Yushania niitakayamensis; Poaceae) in Taiwan. Mol. Ecol. 8: 263-270.

Huff DR, Peakall R and Smouse PE (1993). RAPD variation within and among natural populations of outcrossing buffalograss [Buchloë dactyloides (Nutt.) Engelm.]. Theor. Appl. Genet. 86: 927-934.

Hug LA and Roger AJ (2007). The impact of fossils and taxon sampling on ancient molecular dating analyses. Mol. Biol. Evol. 24: 1889-1897.

Jaccard P (1908). Nouvelles recherches sur la distribution florale. Bull. Soc. Vaudoise Sci. Nat. 44: 223-270.

Landergott U, Holderegger R, Kozlowski G and Schneller JJ (2001). Historical bottlenecks decrease genetic diversity in natural populations of Dryopteris cristata. Heredity 87: 344-355.

Li JC, Ke Y and Li BS (1998). The variation of genetic diversity of Quercus aquifolioides in different elevations. Acta Bot. Sin. 40: 761-767.

Lin RC, Ding ZS, Li LB and Kuang TY (2001). A rapid and efficient DNA minipreparation suitable for screening transgenic plants. Plant Mol. Biol. 19: 379a-379e.

McLellan AJ, Prati D, Kaltz O and Schmid B (1997). Structure and Analysis of Phenotypic and Genetic Variation in Clonal Plants. In: The Ecology and Evolution of Clonal Plants (de Kroon H and Van Groenendael JM, eds.). Backhuys, Leiden, 185-210.

Meimberg H, Thalhammer S, Brachmann A and Heubl G (2006). Comparative analysis of a translocated copy of the trnK intron in carnivorous family Nepenthaceae. Mol. Phylogenet. Evol. 39: 478-490.

Nybom, H and Bartish IV (2000). Effects of life history traits and sampling strategies on genetic diversity estimates obtained with RAPD markers in plants. Persp. Plant Ecol. Evol. Syst. 3: 93-114.

Otero-Arnaiz A, Casas A, Hamrick JL and Cruse-Sanders J (2005). Genetic variation and evolution of Polaskia chichipe (Cactaceae) under domestication in the Tehuacan Valley, central Mexico. Mol. Ecol. 14: 1603-1611.

Oyama K, Hernández-Verdugo S, Sánchez C, González- Rodríguez A, et al. (2006). Genetic structure of wild and domesticated populations of Capsicum annuum (Solanaceae) from Northwestern Mexico analyzed by RAPDs. Genet. Resour. Crop Evol. 53: 553-562.

Pickersgill B (1969). The Domestication of Peppers. In: The Domestication and Exploitation of Plants and Animals (Ucko PJ and Dimbley GW, eds.). Duckworth, London, 443-450.

Rath P, Rajeseger G, Cheng JG and Kumar PP (1998). Phylogenetic analysis of Dipterocarpus using random amplified polymorphic DNA markers. Ann. Bot. 82: 61-65.

Sabrina R and Sabri S (1999). Genetic diversity in natural Cupressus sempervirens L. populations in Turkey. Biochem. Syst. Ecol. 27: 799-814.

Semang K, Bjornstad A and Stedje B (2003). Genetic diversity and differentiation in Ethiopian populations of Phytolacca dodecandra as revealed by AFLP and RAPD analyses. Genet. Resour. Crop Evol. 50: 649-661.

Shimizu Y, Ando M and Sakai F (2002). Clonal structure of natural populations of Cryptomeria japonica growing at different positions on slopes, detected using RAPD markers. Biochem. Syst. Ecol. 30: 733-748.

Sun Y, Xia N and Stapleton CMA (2005). Relationship between Bambusa species (Poaceae, Bambusoidae) revealed by random amplified polymorphic DNA. Biochem. Syst. Ecol. 34: 417-423.

Vivier MA and Pretorius IS (2002). Genetically tailored grapevines for the wine industry. Trends Biotechnol. 20: 472-478.

Yan T, Yan X and Zu Y (1999). A primaryly discuss on the adaptive mechanism at different altitude level of Rhodiola sachalinensis population. Bull. Bot. R 19: 201-206.

Young AG, Hill JH, Murray BG and Peakall R (2002). Breeding system, genetic diversity and clonal structure in the subalpine forb Rutidosis leiolepis F. Muell. (Asteraceae). Biol. Conserv. 106: 71-78.

Zeder MA, Emshwiller E, Smith BD and Bradley DG (2006). Documenting domestication: the intersection of genetics and archaeology. Trends Genet. 22: 139-155.

Zhao LF, Li S, Pan Y, Yan GG, et al. (2001). Population differentiation of Psathyrostachys huashanina along an altitudinal gradient detected by random amplified polymorphic DNA. Acta Bot. Boreali-Occidentalia Sin. 21: 391-400.

Zohary D and Hope M (2000). The Domestication of the Plants in the Old World: The Origin and Spread of Cultivated Plants in West Asia, Europe and Nile Valley. 3rd edn. Oxford University Press, Oxford. 